\title{
TREATMENT OF MANGANESE IN ACID AND NEUTRAL MINE DRAINAGE USING MODIFIED DOLOMITE
}

\author{
IULIANA LAURA CALUGARU ${ }^{1}$, THOMAS GENTY' ${ }^{1,2}$ \& CARMEN MIHAELA NECULITA ${ }^{3}$ \\ ${ }^{1}$ Technology Center for Industrial Waste (Centre Technologique des Résidus Industriels - CTRI), Canada \\ ${ }^{2}$ Agnico Eagle Mines Limited, Canada \\ ${ }^{3}$ Research Institute on Mines and Environment (RIME), University of Quebec in Abitibi-Temiscamingue, Canada
}

\begin{abstract}
The treatment of manganese $[\mathrm{Mn}]$ in acid mine drainage (AMD) and neutral mine drainage (NMD) is prone to variation in performance, which depends on several factors, including $\mathrm{pH}, \mathrm{Mn}$ and dissolved oxygen (DO) concentrations, catalysis by Mn-/iron [Fe]-solids, presence of ligands, and bacteria. Notwithstanding the recent technological and scientific advancements, Mn removal is notoriously difficult and still challenging because of its complex chemistry and high solubility. Precipitation of $\mathrm{Mn}$ (II), in AMD and NMD, occurs in the form of oxides, with prior oxidation to $\mathrm{Mn}(\mathrm{III})$ and $\mathrm{Mn}(\mathrm{IV})$, or as carbonates and sulphides. However, most treatment systems have limited efficiency in simultaneously treating $\mathrm{Mn}$ and other metals in AMD/NMD, necessitating secondary treatment for Mn removal. Modification of natural or residual materials was found efficient for the treatment of NMD. In this context, this study evaluated the performance of half-charred dolomite $\left(1 \mathrm{~h}\right.$ at $\left.750^{\circ} \mathrm{C}\right)$ in batch testing (solid: liquid ratio of $3 \mathrm{~g}: 400 \mathrm{~mL}$ ) for $\mathrm{Mn}$ treatment in AMD and NMD. Results showed that modified dolomite treated more than $98 \% \mathrm{Mn}$ in synthetic NMD (pH 6.1-6.3, up to $1 \mathrm{~g} / \mathrm{L} \mathrm{Mn}$ ), at final $\mathrm{pH}$ of 9.7-10.6. Similar efficiency (98\%) in Mn removal was also found for synthetic AMD (pH 3.6, up to $100 \mathrm{mg} / \mathrm{L}$ $\mathrm{Mn}$ and $1 \mathrm{~g} / \mathrm{L} \mathrm{Fe}, \mathrm{Mn}: \mathrm{Fe}$ molar ratio 1:10), while Fe was completely treated, at final $\mathrm{pH}$ of 9.7-9.8. In addition, Mn removal was $99.5 \%$ within the first $2 \mathrm{~h}$ (when $\mathrm{pH}$ increased to 8.0), while after $4 \mathrm{~h}$, the efficiency was up to $99.9 \%$ (at final $\mathrm{pH}$ of 9.6). DO also decreased (from 8 to $2.2 \mathrm{mg} / \mathrm{L}$ ), at initial $\mathrm{Mn}$ concentrations of $1 \mathrm{~g} / \mathrm{L}$, and dropped (from 8 to $0.7 \mathrm{mg} / \mathrm{L}$ ), when Fe concentrations increased to $1 \mathrm{~g} / \mathrm{L}$ (Mn:Fe molar ratio 1:10). Based on these findings, half-charred dolomite seems a promising option for the treatment of $\mathrm{Mn}$ in both AMD and NMD.
\end{abstract}

Keywords: acid mine drainage, Mn treatment, modified dolomite, neutral mine drainage.

\section{INTRODUCTION}

Mining operations can adversely affect the physicochemical and biological quality of the surrounding surface and ground waters in terms of $\mathrm{pH}$ (acidic/alkaline) and concentrations of toxic metals (e.g., aluminium [Al], cadmium [Cd], cobalt [Co], chromium [Cr], copper [Cu], $\mathrm{Fe}$, mercury [Hg], Mn, molybdenum [Mo], nickel [Ni], lead [Pb], uranium [U], zinc [Zn]), metalloids (e.g., arsenic [As], antimony [Sb], selenium [Se]), as well as polyatomic anions [e.g., sulphate $\left(\mathrm{SO}_{4}{ }^{2-}\right)$, cyanide $\left(\mathrm{CN}^{-}\right)$, thiocyanate $\left(\mathrm{SCN}^{-}\right)$, cyanate $\left(\mathrm{OCN}^{-}\right)$, nitrite $\left(\mathrm{NO}_{2}^{-}\right)$, nitrate $\left(\mathrm{NO}_{3}^{-}\right)$] and cations [e.g., ammonium $\left.\left(\mathrm{NH}_{4}^{+}\right)\right][1-4]$.

Among the above-mentioned contaminants, Mn is notoriously difficult to remove from mine effluents prior to their discharge into the environment, mainly due to the high solubility of its minerals relative to other metals, inhibition of $\mathrm{Mn}$ precipitation at a molar ratio $\mathrm{Fe} / \mathrm{Mn}$ $>4$, reductive dissolution of Mn oxides by organic matter, sulphides and $\mathrm{Fe}(\mathrm{II})$, as well as the high $\mathrm{pH}(>8)$ required for its oxides formation and precipitation [5-8].

In acidic $(\mathrm{pH}<6)$ and neutral ( $\mathrm{pH} 6-8)$ mine drainage (AMD and NMD, respectively), the soluble $\mathrm{Mn}$ (II) form is present [9-11]. The oxidation of Mn to higher oxidation states (III and IV) to form slightly soluble oxides occurs at neutral $\mathrm{pH}$ in the presence of Mn-oxidizing bacteria, commonly present in nature [7,8]. Thus, the oxidation requires a growth surface for the above-mentioned aerobic heterotrophic bacteria and sufficient DO, while the formation 


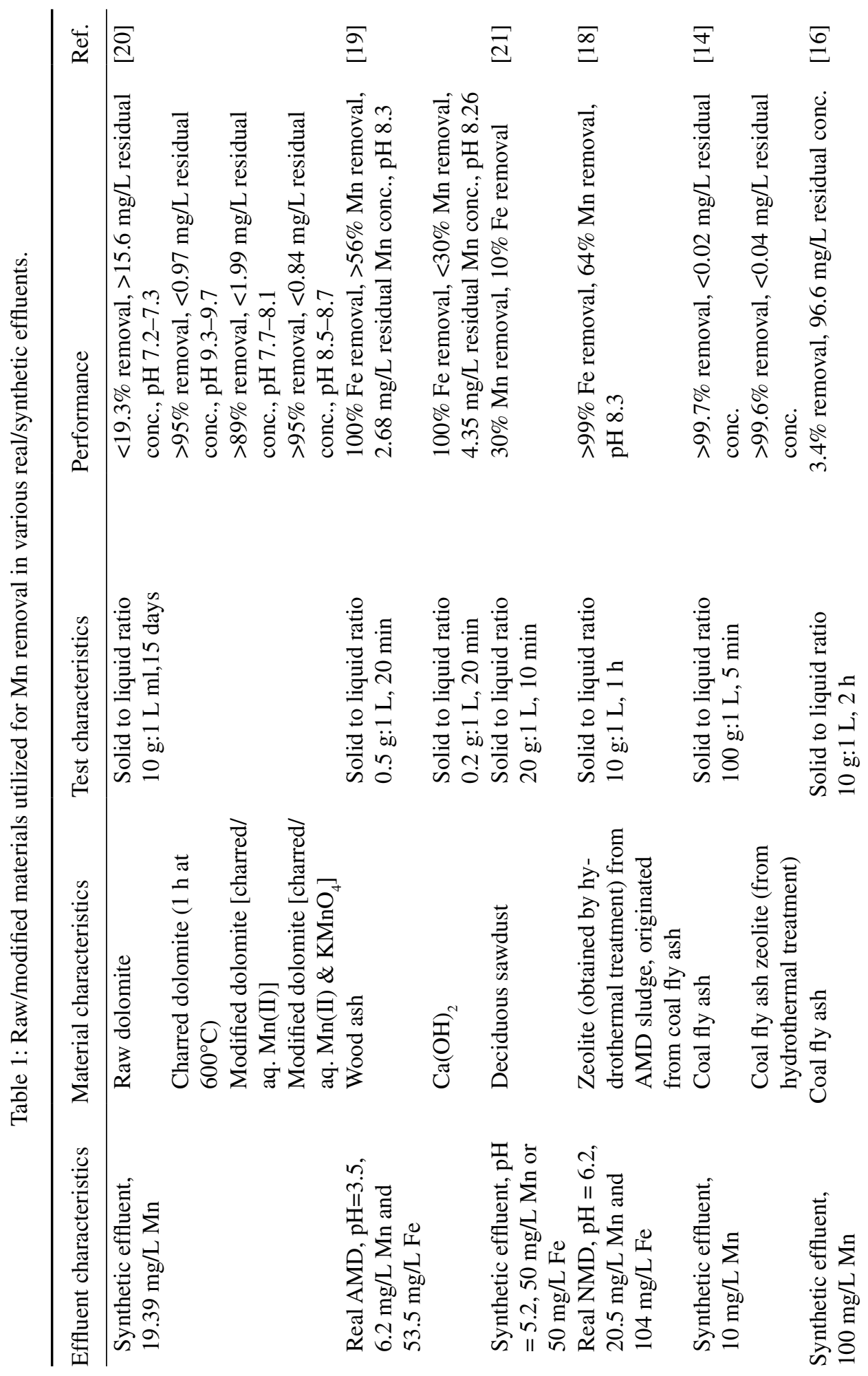




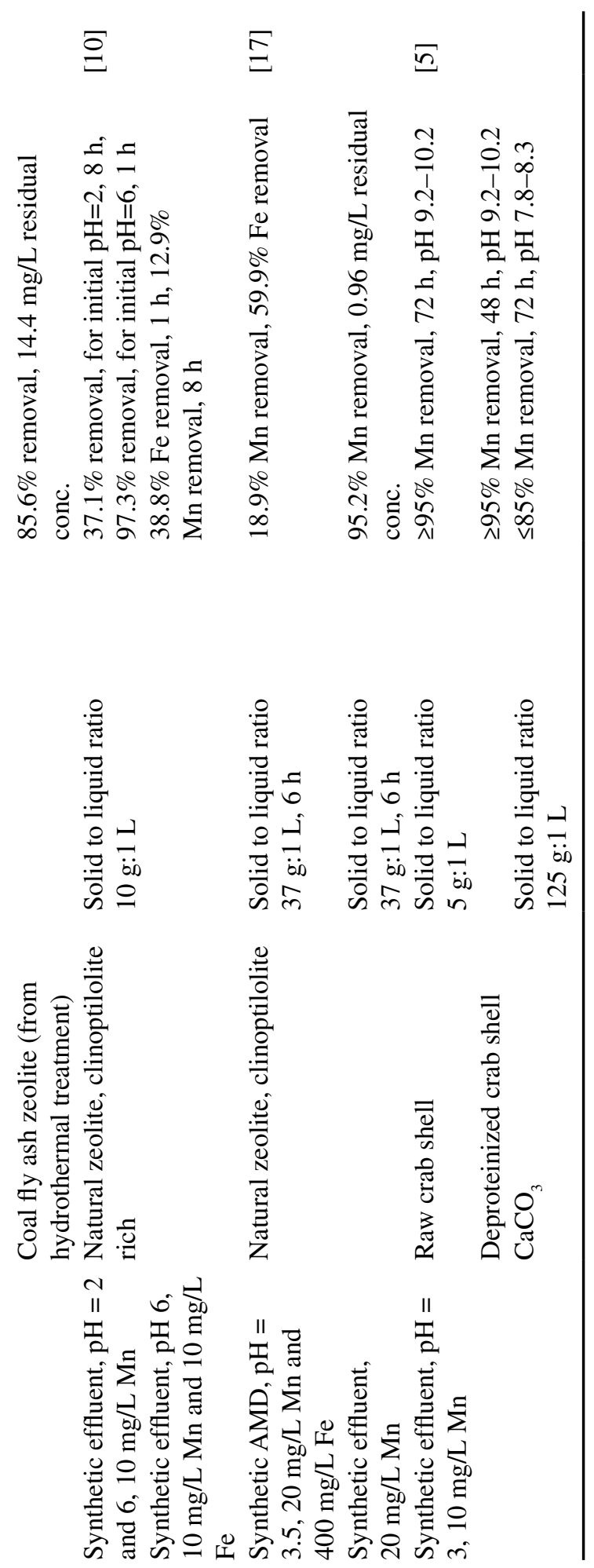


and precipitation of Mn oxides are autocatalytic. Nevertheless, the major hurdle for an efficient $\mathrm{Mn}$ removal is represented by the dissolved $\mathrm{Fe}(\mathrm{II})$, which is adsorbed on the surface of Mn oxides and reduces them to Mn(II) soluble [7, 8]. Besides oxides, Mn(II) can be removed from mine effluents as sulphides and carbonates, under reducing and alkaline conditions [5, 12]. In general, the effective removal of $\mathrm{Mn}$ from mine drainage requires additional polishing steps in the design of the treatment systems, to priorly reduce $\mathrm{Fe}$ and $\mathrm{Al}$ concentrations $[8,13]$.

To limit the cost of Mn treatment, several natural and residual materials were evaluated, including the following: hydrated lime $\left[\mathrm{Ca}(\mathrm{OH})_{2}\right]$, limestone $\left(\mathrm{CaCO}_{3}\right)$, montmorillonite, bentonite, hydrotalcite, natural zeolite, coal fly ash and its hydrothermal synthetic zeolite, sludge originated zeolite, dolomite $\left[\mathrm{CaMg}\left(\mathrm{CO}_{3}\right)_{2}\right]$ and activated dolomite, raw and deproteinized crab shells, Fe(III)-impregnated activated carbon, sawdust and wood ash [5, 8, 10, 11, 14-21]. However, some of these materials (Table 1), such as dolomite and activated dolomite, deciduous sawdust, coal fly ash and coal fly ash zeolite, natural zeolite, limestone, and raw and deproteinized crab shells, were evaluated for Mn removal in synthetic effluents, in the absence of Fe. In addition, except for the raw dolomite and deciduous sawdust, the referred to materials were found effective for Mn removal at concentrations less than $20 \mathrm{mg} / \mathrm{L}$. Nonetheless, the fastest kinetics ( $5 \mathrm{~min}$ ) were observed for the coal fly ash and its synthetic zeolite [14], whereas the slowest kinetics (15 days) were observed for the activated dolomite [20]. Conversely, whenever the $\mathrm{Fe}$ is present, in either real or synthetic effluents, Mn removal is adversely affected, as in the case of wood ash and hydrated limestone [19], sludge originated zeolite [18] or natural zeolite [10].

Among the materials evaluated for Mn removal, dolomite (a sedimentary carbonate mineral, worldwide spread and available at low cost) was found efficient for the treatment of several metals and metalloids (including in mine drainage), such as $\mathrm{Pb}, \mathrm{Cd}, \mathrm{Cu}, \mathrm{Ag}, \mathrm{Co}$, and As [22-27]. Moreover, thermal activation considerably enhanced its efficiency for the removal of $\mathrm{As}, \mathrm{Co}, \mathrm{Cr}, \mathrm{Mn}, \mathrm{Ni}$ and $\mathrm{Zn}$ [20, 28-31]. Thermally activated dolomite was also found effective for the treatment of several metals ( $\mathrm{Ag}, \mathrm{As}, \mathrm{B}, \mathrm{Ba}, \mathrm{Co}, \mathrm{Cr}, \mathrm{Hg}, \mathrm{Mn}, \mathrm{Ni}, \mathrm{Pb}$, $\mathrm{Sn}, \mathrm{Sr}, \mathrm{Ti}$ and V) in a shipyard wastewater [32].

In this context, the objective of this study was to comparatively evaluate the performance of raw and half-charred dolomite, for Mn treatment in NMD or in AMD, in the presence of $\mathrm{Fe}(\mathrm{Mn}: \mathrm{Fe}$ molar ratio of 1:10).

\section{MATERIALS AND METHODS}

\subsection{Raw and activated dolomite}

The dolomite rock used in this study was provided by Temiska Silice (Saint-Bruno-de-Guigues, Quebec, Canada). Its thermal activation was performed by charring in an oven (Thermolyne Furnace) for $1 \mathrm{~h}$, at $750^{\circ} \mathrm{C}$. These activation conditions were found optimal in a previous study where $\mathrm{Ni}$ and $\mathrm{Zn}$ were successfully treated in NMD [31].

Both raw and charred dolomite samples were first grinded. Then, the following physicochemical parameters were determined: particle size distribution, specific surface, $\mathrm{pH}, \mathrm{pH}_{\mathrm{PZC}}$, elemental composition and mineralogy [31].

Thermal decomposition of dolomite produces [20, 28-30] either a mixture of $\mathrm{CaCO}_{3}$ (calcite) and $\mathrm{MgO}$ (periclase, resulting from the dissociation of $\mathrm{MgCO}_{3}$ ) (eqn (1)) or $\mathrm{MgO}$ and $\mathrm{CaO}$, by further decomposition of $\mathrm{CaCO}_{3}$ (eqn (2)). If the process is stopped at $\approx 800^{\circ} \mathrm{C}$, a 
Table 2: Conditions used in treatability testing.

\begin{tabular}{|c|c|c|c|c|c|}
\hline $\begin{array}{l}\text { Effluent/ } \\
\text { dolomite type }\end{array}$ & Parameter & Metal & $\mathrm{pH}$ & Sampling (h) & Doses (mg/L) \\
\hline NMD/raw & \multirow{3}{*}{$\begin{array}{l}\text { Uptake } \\
\text { function of } \\
\text { concentration }\end{array}$} & \multirow{3}{*}{$\mathrm{Mn}$} & $6.2-6.3$ & & $50,100,153,202$ \\
\hline NMD/charred & & & $6.1-6.3$ & 48 & $\begin{array}{l}50,100,153,202, \\
\quad 426,1353,1815,2693\end{array}$ \\
\hline AMD/charred & & & 36 & & $\begin{array}{l}58 / 443,99 / 934 \\
145 / 1470,188 / 1860\end{array}$ \\
\hline $\begin{array}{l}\text { NMD/raw } \\
\text { NMD/charred }\end{array}$ & $\begin{array}{l}\text { Uptake } \\
\text { function of } \\
\text { time }\end{array}$ & Mn & 6.7 & $\begin{array}{c}1,2,4,8,24 \\
48\end{array}$ & 77.5 \\
\hline
\end{tabular}

solid rigid mixture of calcite and periclase is obtained. This new material has a porous structure, with over 50 times the specific surface area of the raw dolomite [29, 31-33]:

$$
\begin{gathered}
\mathrm{CaMg}\left(\mathrm{CO}_{3}\right)_{2} \rightarrow \mathrm{CaCO}_{3}+\mathrm{MgO}+\mathrm{CO}_{2} \\
\mathrm{CaCO}_{3} \rightarrow \mathrm{CaO}+\mathrm{CO}_{2}
\end{gathered}
$$

\subsection{Synthetic effluents (solutions)}

The performance of raw and half-charred dolomite was assessed using synthetic effluents (NMD and AMD) prepared with ACS grade of sulphate salts $\left(\mathrm{MnSO}_{4} \cdot \mathrm{H}_{2} \mathrm{O}\right.$ and $\left.\mathrm{FeSO}_{4} \cdot 7 \mathrm{H}_{2} \mathrm{O}\right)$ and deionized water (Table 2). The $\mathrm{pH}$ of the AMD was adjusted with concentrated (98\%) $\mathrm{H}_{2} \mathrm{SO}_{4}$. The ionic strength for both NMD and AMD types of effluents was adjusted with solid $\mathrm{NaCl}$.

\subsection{Batch testing conditions, sampling, analysis and data processing}

The experiments were conducted in $50 \mathrm{~mL}$ propylene tubes containing a volume of $40 \mathrm{~mL}$ synthetic effluent, at a temperature of $25^{\circ} \mathrm{C}$ and at $300 \mathrm{rpm}$ agitation speed. The solid to liquid ratio $(3 \mathrm{~g}: 400 \mathrm{~mL})$ was selected according to the literature [24, 31]. The maximum Mn concentration in the synthetic NMD (pH 6.1-6.3) was $202 \mathrm{mg} / \mathrm{L}$ (for the raw dolomite) and 2,693 $\mathrm{mg} / \mathrm{L}$ (for the half-charred dolomite) (Table 2). In the synthetic AMD (pH 3.6), the maximum $\mathrm{Mn}$ and Fe concentrations were 188 and 1,860 mg/L, respectively. Solely the halfcharred dolomite was evaluated for the treatment of the synthetic AMD (Table 2). Nitrogen was purged for $2 \mathrm{~min}$, within each propylene tube. At the end of the $48 \mathrm{~h}$ batch experiments, the supernatant was filtered, the $\mathrm{pH}$ and DO were measured, while the concentrations of $\mathrm{Mn}$ and $\mathrm{Fe}$ were analysed with an AA spectrometer. Additional batch testing was performed in order to evaluate the uptake of $\mathrm{Mn}$ in synthetic NMD (pH 6.7) as a function of time. The synthetic NMD contained $77.5 \mathrm{mg} / \mathrm{L} \mathrm{Mn}$, and the sampling was carried out at 1, 2, 4, 8, 24 and $48 \mathrm{~h}$ (Table 2). The $\mathrm{pH}$, and the DO and Mn concentrations were measured for each filtered sample. 
Metal removal (\%) was calculated with eqn (3):

$$
\% \text { Removal }=\left[C_{o}-C_{f}\right] .100 / C_{o}
$$

where $\mathrm{C}_{0}$ and $\mathrm{C}_{\mathrm{f}}$, represent, respectively, the initial and final concentrations of metal in solution $(\mathrm{mg} / \mathrm{L})$.

\section{RESULTS AND DISCUSSION}

\subsection{Materials characterization}

The dolomite samples used in this study had high purity (87.1\%). After $1 \mathrm{~h}$ of charring at $750^{\circ} \mathrm{C}, 7.2 \%$ of the solid consisted of dolomite, while two new mineral phases appeared, i.e. calcite $(53.7 \%)$ and periclase $(19.9 \%)$. The resulting charred dolomite (pH 11.6) showed strongly basic relative to the raw dolomite $(\mathrm{pH} 7.9)$, while the $\mathrm{pH}_{\mathrm{PZC}}$ of raw dolomite increased from 9.6 to 11.1 after the charring. A sevenfold increase in specific surface $\left(0.6-4.2 \mathrm{~m}^{2} / \mathrm{g}\right)$ was also observed for the charred dolomite [31].

\subsection{Batch testing results}

Charred dolomite showed very effective for Mn removal in the synthetic NMD, as more than $89 \%$ of Mn was removed from solutions initially contaminated up to $1,353 \mathrm{mg} / \mathrm{L}$ (Table 3).

Minor residual concentrations (up to $3.3 \mathrm{mg} / \mathrm{L}$ ) of $\mathrm{Mn}$ in the treated NMD were found only up to maximum initial concentration of $892 \mathrm{mg} / \mathrm{L}$ (Table 3). Effectiveness of the charred dolomite then decreased, when Mn concentration increased above $892 \mathrm{mg} / \mathrm{L}$ in the synthetic NMD, whereas raw dolomite seemed sparsely effective even at low (49.6 mg/L) Mn

Table 3: Performance of raw and charred dolomite for Mn removal in synthetic NMD as a function of the initial concentration, in batch testing.

\begin{tabular}{lcccc}
\hline $\mathrm{C}_{0}(\mathrm{mg} / \mathrm{L})$ & $\mathrm{C}_{\mathrm{f}}(\mathrm{mg} / \mathrm{L})$ & Removal $(\%)$ & $\mathrm{pH}$ & $\mathrm{DO}(\mathrm{mg} / \mathrm{L})$ \\
\hline 49.6 & 43.7 & Dolomite & 8.7 \\
99.9 & 91.5 & 11.9 & 7 & 8.6 \\
153.3 & 148.4 & 8.4 & 6.8 & 8.3 \\
202.3 & 196.1 & 3.2 & 6.7 & 8.2 \\
\hline \multicolumn{5}{c}{ Charred dolomite } \\
\hline 49.6 & 1.4 & 97.2 & 6.6 & 7.9 \\
99.9 & 1.5 & 98.5 & 10.6 & 7.7 \\
153.3 & 3.1 & 98.0 & 10.5 & 6.9 \\
202.3 & 3.3 & 98.4 & 10.4 & 6.3 \\
426 & 0.02 & 99.9 & 10.3 & 4.1 \\
892 & 0.04 & 99.9 & 10.2 & 2.3 \\
1353 & 147 & 89.1 & 9.7 & 1.4 \\
1815 & 592 & 67.4 & 8.4 & 1.4 \\
2693 & 1350 & 49.9 & 7.8 & 1.7 \\
\hline
\end{tabular}


Table 4: Performance of charred dolomite for Mn removal in the presence of Fe (1:10) in synthetic AMD, as a function of the initial concentration, in batch testing.

\begin{tabular}{lcccccccc}
\hline Mn & \multicolumn{4}{c}{ Fe } & & \multicolumn{3}{c}{$\begin{array}{l}\text { Mn:Fe } \\
\text { Final ratio }\end{array}$} \\
\hline $\mathrm{C}_{0}$ & $\mathrm{C}_{\mathrm{f}}$ & Removal & $\mathrm{C}_{0}$ & $\mathrm{C}_{\mathrm{f}}$ & Removal \\
$(\mathrm{mg} / \mathrm{L})$ & $(\mathrm{mg} / \mathrm{L})$ & $(\%)$ & $(\mathrm{mg} / \mathrm{L})$ & $(\mathrm{mg} / \mathrm{L})$ & $(\%)$ & & & \\
57.6 & 0.005 & 99.9 & 443 & $\mathrm{BDL}$ & 99.9 & $\mathrm{~N} / \mathrm{A}$ & 9.8 & 3.33 \\
99 & 1.5 & 98.5 & 934 & $\mathrm{BDL}$ & 99.9 & $\mathrm{~N} / \mathrm{A}$ & 9.7 & 0.72 \\
145 & 107 & 26.2 & 1470 & 145 & 90.1 & $1: 1.3$ & 6.9 & 0.24 \\
188 & 162 & 13.8 & 1860 & 714 & 61.6 & $1: 4.3$ & 6.8 & 0.13 \\
\hline
\end{tabular}

BDL: below detection limit; N/A: not applicable.

concentrations (Table 3). The initial $\mathrm{pH}$ of the uptake experiments was 6.1-6.3, whereas the final $\mathrm{pH}$ was 7-6.6 (for the raw dolomite) and 10.6-7.5 (for the charred dolomite).

Solely charred dolomite was evaluated for the treatment of $\mathrm{Mn}$ in the presence of Fe (1:10), in synthetic AMD (pH 3.6), and it was found effective up to $99 \mathrm{mg} / \mathrm{L} \mathrm{Mn}$ and $934 \mathrm{mg} / \mathrm{L} \mathrm{Fe}$ (Table 4).

It was observed that further increase of Fe concentration significantly decreased $\mathrm{Mn}$ removal, consistently with previously reported findings [10, 18, 19]. Fe removal was satisfactory $(90 \%)$ up to $1,470 \mathrm{mg} / \mathrm{L}$ as initial concentration, but residual Fe was usually high $(145 \mathrm{mg} / \mathrm{L})$ in treated AMD (Table 4).

The $\mathrm{pH}$ varied from basic to neutral while DO concentration was significantly reduced. Oxidation of $\mathrm{Fe}$ (II) to $\mathrm{Fe}$ (III) followed by $\mathrm{Fe}$ (III) hydrolysis could explain the decrease of both $\mathrm{DO}$ and $\mathrm{pH}$.

The results of batch testing on the uptake of Mn in synthetic NMD as a function of time (Table 5) were consistent with the previous results of this study. Hence, dolomite showed limited efficiency, whereas charred dolomite allowed significant reduction of Mn concentration within only $2 \mathrm{~h}$ of contact with the synthetic NMD. Noteworthy, $80 \%$ of Mn was removed within $1 \mathrm{~h}$; however, residual Mn concentration was still high $(15.6 \mathrm{mg} / \mathrm{L})$. The initial $\mathrm{Mn}$ and DO concentrations were 77.5 and $8.1 \mathrm{mg} / \mathrm{L}$, respectively, at a $\mathrm{pH}$ of 6.7. The DO recorded little variation for both raw and charred dolomite. The neutralizing effect of dolomite seemed slow compared to charred dolomite (that settled to 10.4 after $24 \mathrm{~h}$ ). Consequently, to explain $\mathrm{Mn}$ removal, chemical sorption seems more probable than oxidation and precipitation, as $\mathrm{Mn}$ concentrations dropped from 77.5 to $0.37 \mathrm{mg} / \mathrm{L}$ within $2 \mathrm{~h}$, whereas $\mathrm{pH}$ raised from 6.7 to 8 within the same interval of time.

3.3 Comparative performance of half-charred dolomite and some recently evaluated raw and modified materials for Mn treatment

The performance of some materials such as raw and activated dolomite, hydrated lime, limestone, wood ash and sawdust, natural zeolite, coal fly ash and coal fly ash zeolite, synthetic zeolite prepared from sludge resulting from the AMD treatment with coal fly ash, raw and deproteinized crab shell, recently evaluated for the treatment of $\mathrm{Mn}$ in different aqueous solutions, is presented in Table 1. 
Table 5: Performance of charred dolomite for Mn removal in synthetic NMD as a function of time, in batch testing.

\begin{tabular}{|c|c|c|c|c|}
\hline Time (h) & $\mathrm{C}_{\mathrm{f}}(\mathrm{mg} / \mathrm{L})$ & Removal (\%) & $\mathrm{pH}$ & $\mathrm{DO}(\mathrm{mg} / \mathrm{L})$ \\
\hline \multicolumn{5}{|c|}{ Dolomite } \\
\hline 0 & 77.5 & 0.0 & 6.7 & 8.1 \\
\hline 1 & 72.5 & 6.5 & 6.8 & 8.0 \\
\hline 4 & 70 & 9.7 & 6.8 & 7.0 \\
\hline 24 & 70.5 & 9.0 & 6.9 & 8.0 \\
\hline 48 & 69 & 11.0 & 8.2 & 8.0 \\
\hline \multicolumn{5}{|c|}{ Charred dolomite } \\
\hline 0 & 77.5 & 0.0 & 6.7 & 8.1 \\
\hline 1 & 15.6 & 79.9 & 7.2 & 7.5 \\
\hline 2 & 0.37 & 99.5 & 8.0 & 6.8 \\
\hline 4 & 0.01 & 99.9 & 9.6 & 7.22 \\
\hline 8 & 0 & 100 & 9.8 & 7.49 \\
\hline 24 & 0.1 & 99.9 & 10.4 & 7.0 \\
\hline 48 & 0.01 & 99.9 & 10.4 & 7.2 \\
\hline
\end{tabular}

Among natural materials, raw dolomite seems the least effective [20], natural zeolite the most effective $[10,17]$, whereas an important solid to liquid ratio is necessary to improve the effectiveness of the limestone [5] for Mn removal.

Concerning the waste materials, the least effective seems the sawdust of deciduous trees, and the most effective the coal fly ash and the raw crab shell. In the same time, Mn removal is faster by fly ash ( $>99.7 \%$ removal within $5 \mathrm{~min}$ ) than by raw crab shell ( $\geq 95 \% \mathrm{Mn}$ removal within $72 \mathrm{~h}$ ).

Modification of natural and waste materials improves their performance in Mn withdrawal. For instance, modified dolomite [20] becomes very effective in terms of \% removal ( $>95 \%)$ and residual $\mathrm{Mn}$ concentration $(<0.84 \mathrm{mg} / \mathrm{L})$ while maintaining a neutral $\mathrm{pH}$ of treated effluent (8.5-8.7). However, the initial concentration of $\mathrm{Mn}$ was lower (about $20 \mathrm{mg} / \mathrm{L}$ ) compared to this study ( $892 \mathrm{mg} / \mathrm{L}$ ), whereas the duration of batch testing was longer ( $15 \mathrm{vs} 2$ days). It is to observe that half-charred dolomite evaluated in this study decreased the Mn concentration from 77.5 to $0.37 \mathrm{mg} / \mathrm{L}$ within $2 \mathrm{~h}$, while the $\mathrm{pH}$ of the treated effluent was 8.0. The solid to liquid ratio in this study was $7.5 \mathrm{~g}$ for $1 \mathrm{~L}$, which is comparable to $10 \mathrm{~g}$ for $1 \mathrm{~L}$, employed by Mamchenko et al. [20].

Coal fly ash seems effective for Mn removal at low initial concentrations [14] (10 mg/L, $>99.7 \%$ removal), but less effective at higher initial concentrations ( $100 \mathrm{mg} / \mathrm{L}, 3.4 \%$ removal) [16]. Yet, its conversion into zeolite improves the performance for Mn removal (100 mg/L, $85.6 \%)$ [16].

Although very effective for Mn removal, natural zeolite seems to significantly lose its efficiency wherever Fe is present $[10,17]$. However, synthetic zeolite prepared by hydrothermal treatment of sludge originated from AMD treatment with coal fly ash, removed $99 \% \mathrm{Fe}$ and $64 \% \mathrm{Mn}$ from a real NMD (pH 6.2, $20.5 \mathrm{mg} / \mathrm{L} \mathrm{Mn}$, and $104 \mathrm{mg} / \mathrm{L} \mathrm{Fe}$ ) while maintaining the $\mathrm{pH}$ of the final effluent at 8.3 [18].

Better performance was obtained by half-charred dolomite, within this study, as $\mathrm{Mn}$ and Fe were removed up to $98.5 \%$ (1.5 $\mathrm{mg} / \mathrm{L}$ residual concentration) and $99.9 \%$ (BDL) respectively, from a synthetic AMD (pH 3.6, $99 \mathrm{mg} / \mathrm{L} \mathrm{Mn}$, and $934 \mathrm{mg} / \mathrm{L} \mathrm{Fe})$. 


\section{CONCLUSIONS}

In this study, both raw and half-charred dolomite $\left(1 \mathrm{~h}\right.$, at $\left.750^{\circ} \mathrm{C}\right)$ were evaluated through batch testing for their performance in Mn removal from synthetic AMD and NMD. The results showed that charred dolomite treated more than 98\% Mn in synthetic NMD (pH 6.16.3) when the initial Mn concentration was up to $892 \mathrm{mg} / \mathrm{L}$. Moreover, Mn removal was very efficient (89\%) when the initial Mn concentration was $1,353 \mathrm{mg} / \mathrm{L}$. Nonetheless, the residual concentration was $147 \mathrm{mg} / \mathrm{L} \mathrm{Mn}$. The uptake kinetic was relatively fast, as Mn concentration dropped from 77.5 to $0.37 \mathrm{mg} / \mathrm{L}$ within $2 \mathrm{~h}$. However, $79.9 \% \mathrm{Mn}$ was removed within the first $1 \mathrm{~h}$. Meanwhile, raw dolomite showed poor performance in the same testing conditions.

In synthetic AMD ( $\mathrm{pH} 3.6, \mathrm{Mn}: \mathrm{Fe}$ molar ratio 1:10), better performance in $\mathrm{Mn}$ and Fe removal was achieved at maximum initial concentrations of 99 and $934 \mathrm{mg} / \mathrm{L}$, respectively. Above 1,470 mg/L, Fe removal was still satisfactory $(90.1 \%)$, despite the fact that residual Fe was high (145 mg/L), whereas Mn removal was poor $(29.2 \%$ for $145 \mathrm{mg} / \mathrm{L}$ initial concentration).

Half-charring of dolomite strongly enhanced its alkaline character and neutralizing capacity. However, the $\mathrm{pH}$ increase seems rather slow to cause an eventual major removal of $\mathrm{Mn}$ by precipitation, as $99.5 \%$ of $\mathrm{Mn}$ was removed from $77.5 \mathrm{mg} / \mathrm{L}$ initial $\mathrm{Mn}$ concentration at a final $\mathrm{pH}$ of 8.0.

The most severe drop in DO was found during AMD treatment. As simultaneously decrease of $\mathrm{pH}$ was also observed, $\mathrm{Fe}$ (II) was probably partially oxidized to $\mathrm{Fe}$ (III), which then hydrolysed and precipitated. An important decrease of DO was also observed at higher concentrations of Mn in NMD (above $426 \mathrm{mg} / \mathrm{L}$ ). In this last case, $\mathrm{Mn}(\mathrm{II})$ probably precipitated as oxidized Mn(III) or Mn(IV).

Based on these findings, half-charred dolomite could be considered as a promising option for the treatment of Mn in both AMD and NMD. Further research is warranted to evaluate the mechanisms of Mn removal.

\section{ACKNOWLEDGEMENTS}

This research was supported by the Natural Sciences and Engineering Research Council of Canada (NSERC), the College of Abitibi-Témiscamingue and the industrial partners of the Centre Technologique des Résidus Industriels (Technological Center for Industrial Waste): Regénération, Iamgold Corporation, Hecla Québec, Mine Canadian Malartic, Technosub and the Organisme Bassin Versant du Témiscamingue.

\section{REFERENCES}

[1] Acheampong, M.A., Meulepas, R.J.W. \& Lens, P.N.L., Removal of heavy metals and cyanide from gold mine wastewater. Journal of Chemical Technology and Biotechnology, 85(5), pp. 590-613, 2010. DOI: 10.1099/00221287-10-2-261.

[2] Nordstrom, D.K., Mine waters: Acidic to circumneutral. Elements, 7(6), pp. 393-398, 2011. DOI: $10.2113 / \mathrm{gselements.7.6.393.}$

[3] Jermakka, J., Wendling, L., Sohlberg, E., Heinonen, H. \& Vikman, M., Potential technologies for the removal and recovery of nitrogen compounds from mine and quarry waters in subarctic conditions. Critical Reviews in Environmental Science and Technology, 45(7), pp. 703-748, 2015. DOI: 10.1021/es060661h.

[4] Nordstrom, K., Blowes, D.W. \& Ptacek, C.J., Hydrogeochemistry and microbiology of mine drainage: An update. Applied Geochemistry, 57, pp. 3-16, 2015. DOI: 10.1016/j. apgeochem.2015.02.008. 
[5] Robinson-Lora, M.A. \& Brennan, R.A., Anaerobic precipitation of manganese and co-existing metals in mine impacted water treated with crab shell-associated minerals. Applied Geochemistry, 26(5), pp. 853-862, 2011. DOI: 10.1016/j.apgeochem.2011.02.006.

[6] Song, H., Yim, G.-J., Ji, S.-W., Nam, I.H., Neculita, C.M. \& Lee, G.Y., Performance of mixed organic substrates during the treatment of acidic and moderate mine drainage in column bioreactors. Journal of Environmental Engineering, ASCE 138(10), pp. 1077-1084, 2012. DOI: 10.1061/(ASCE)EE.1943-7870.0000567.

[7] Lesley, B. Daniel, H. \& Paul, Y., Iron and manganese removal in wetland treatment systems: Rates, processes and implications for management. Science of the Total Environment, 394, pp. 1-8, 2008. DOI: 10.1016/j.scitotenv.2008.01.002.

[8] Skousen, J., et al., Review of passive systems for acid mine drainage treatment. Mine, Water and the Environment, 36(1), pp. 133-153, 2017. DOI: 10.1007/s10230-016-0417-1.

[9] National Institute of Advanced Industrial Science and Technology Research Center for Deep Geological Environments Naoto TAKENO, Atlas of Eh-pH diagrams, Intercomparison of thermodynamic databases, Geological Survey of Japan Open File Report No. 419, p. 287, May 2005, available at http://www.eosremediation.com/download/ Chemistry/Chemical\%20Properties/Eh_pH_Diagrams.pdf.

[10] García-Mendieta, A., Solache-Ríos, M. \& Olguín, M.T., Evaluation of the sorption properties of a Mexican clinoptilolite-rich tuff for iron, manganese and iron-manganese systems. Microporous and Mesoporous Materials, 118(1-3), pp. 489-495, 2009. DOI: 10.1016/j.micromeso.2008.09.028.

[11] Goldani, E., Moro, C.C. \& Maia, S.M., A study employing different clays for Fe and Mn removal in the treatment of acid mine drainage. Water, Air and Soil Pollution, 224, p. 1401, 2013. DOI: 10.1080/12269328.2010.10541314.

[12] Neculita, C.M., Zagury, G.J. \& Bussière, B., Effectiveness of sulfate-reducing passive bioreactors for treating highly contaminated acid mine drainage: II. Metal removal mechanisms and potential mobility. Applied Geochemistry, 23, pp. 3545-3560, 2008. DOI: 10.1016/j.apgeochem.2008.08.014.

[13] Rakotonimaro, T.V., Neculita, C.M., Bussière, B. \& Zagury, G.J., Effectiveness of various dispersed alkaline substrates for the pretreatment of ferriferous acid mine drainage. Applied Geochemistry, 73, pp. 13-23, 2016. DOI: 10.1016/j.apgeochem.2016.07.014

[14] Belviso, C., et al., Removal of Mn from aqueous solution using fly ash and its hydrothermal synthetic zeolite. Journal of Environmental Management, 137, pp. 16-22, 2014. DOI: 10.1016/j.jenvman.2014.01.040

[15] Mondal, P., Balomajumder, C. \& Mohanty, B., A laboratory study for the treatment of arsenic, iron, and manganese bearing ground water using $\mathrm{Fe}^{3+}$ impregnated activated carbon: Effects of shaking time, $\mathrm{pH}$ and temperature. Journal of Hazardous Materials, 144, pp. 420-426, 2007. DOI: 10.1016/j.jhazmat.2006.10.078.

[16] Nascimento, M., Soares, P.S.M. \& de Souza, V.P. Adsorption of heavy metal cations using coal fly ash modified by hydrothermal method. Fuel, 88, pp. 1714-1719, 2009. DOI: 10.1016/j.fuel.2009.01.007.

[17] Motsi, T., Rowson, N.A. \& Simmons, M.J.H. Adsorption of heavy metals from acid mine drainage by natural zeolite. International Journal of Mineral Processing, 92, pp. 42-48, 2009. DOI: 10.1016/j.minpro.2009.02.005.

[18] Vadapalli, V.R.K., Gitari, W.M., Ellendt, A., Petrik, L.F. \& Balfour, G., Synthesis of zeolite-P from coal fly ash derivative and its utilisation in mine-water remediation. South African Journal of Science, 106(5-6), pp. 1-7, 2010. DOI: 10.4102/sajs.v106i5/6.231. 
[19] Heviánková, S., Bestová, I. \& Kyncl, M., The application of wood ash as reagent in acid mine drainage treatment. Minerals Engineering, 56, pp. 109-111, 2014. DOI: 10.1016/j.mineng.2013.10.032.

[20] Mamchenko, A.V., Kiy, N.N., Chernova, L.G. \& Misochka, I.V., The investigation of the impact of the modification methods of natural dolomite on water demanganesation. Journal of Water Chemistry and Technology, 30(4), pp. 191-196, 2008. DOI: 10.3103/ S1063455X08040012.

[21] Božic, D., Stanković, V., Gorgievski, M., Bogdanović, G. \& Kovačević, R., Adsorption of heavy metal ions by sawdust of deciduous trees. Journal of Hazardous Materials, 171, pp. 684-692, 2009. DOI: 10.1016/j.jhazmat.2009.06.055.

[22] Kokaoba, S., Comparaison of Amberlite IR 120 and dolomite's performances for removal of heavy metals. Journal of Hazardous Materials, 147, pp. 488-496, 2007. DOI: 10.1016/j.jhazmat.2007.01.037.

[23] Ayoub, G.M. \& Mehawej, M. Adsorption of arsenate on untreated dolomite powder. Journal of Hazardous Materials, 148(1-2), pp. 259-266, 2007. DOI: 10.1016/j.jhazmat.2007.02.011.

[24] Pehlivan, E., Özkan, A.M., Dinç, S. \& Parlayici, Ş., Adsorption of $\mathrm{Cu}^{2+}$ and $\mathrm{Pb}^{2+}$ ion on dolomite powder, Journal of Hazardous Materials, 167, pp. 1044-1049, 2009. DOI: 10.1016/j.jhazmat.2009.01.096.

[25] Salameh, Y., Al-Lagtah, N., Ahmad, M.N.M., Allen, S.J. \& Walker, G.M., Kinetic and thermodynamic investigations on arsenic adsorption onto dolomitic sorbents. Chemical Engineering Journal, 160, pp. 440-446, 2010. DOI: 10.1016/j.cej.2010.03.039.

[26] Irani, M., Amjadi, M. \& Mousavian, M.A., Comparative study of lead sorption onto natural perlite, dolomite and diatomite. Chemical Engineering Journal, 178, pp. $317-$ 323, 2011. DOI: 10.1016/j.cej.2011.10.011.

[27] Ghaemi, A., Torab-Mostaedi, M., Shahhosseini, S. \& Asadollahzadeh, M., Characterization of $\mathrm{Ag}(\mathrm{I}), \mathrm{Co}(\mathrm{II})$ and $\mathrm{Cu}(\mathrm{II})$ removal process from aqueous solutions using dolomite powder. Korean Journal of Chemical Engineering, 30(1), pp. 172-180, 2013. DOI: $10.1021 / \mathrm{ie} 0402620$.

[28] Stefaniak, E., Dobrowolski, R. \& Staszczuk, P., On the adsorption of chromium(VI) ions on dolomite and 'dolomitic sorbents'. Adsorption Science \& Technology, 18(2), pp. 107-115, 2000. DOI: 10.1177/026361749901700202.

[29] Salameh, Y., Albadarin, A.B., Allen, S.J., Walker, G. \& Ahmad, M.N.M., Arsenic (III, V) adsorption onto charred dolomite: Charring optimisation and batch studies. Chemical Engineering Journal, 259, pp. 663-671, 2015. DOI: 10.1016/j.cej.2014.08.038.

[30] Ivanets, A.I., Shashkova, I.L., Kitikova, N.V., \& Drozdova, N.V., Extraction of Co(II) ions from aqueous solutions with thermally activated dolomite. Russian Journal of Applied Chemistry, 87(3), pp. 270-275, 2014. DOI: 10.1134/S1070427214030045.

[31] Calugaru, I.L., Neculita, C.M., Genty, T., Bussière B., \& Potvin, R., Performance of thermally activated dolomite for the treatment of $\mathrm{Ni}$ and $\mathrm{Zn}$ in contaminated neutral drainage. Journal of Hazardous Materials, 310, pp. 48-55, 2016. DOI: 10.1016/j.jhazmat.2016.01.069.

[32] Walker, G.M., Hanna, J.-A., \& Allen, S.J., Treatment of hazardous shipyard wastewater using dolomitic sorbents. Water Research, 39(11), pp. 2422-2428, 2005. DOI: 10.1016/j.watres.2005.04.025.

[33] Duffy, A., Walker, G.M. \& Allen, S.J., Investigations on the adsorption of acidic gases using activated dolomite. Chemical Engineering Journal, 117(3), pp. 239-244, 2006. DOI: $10.1016 /$ j.cej.2005.11.016. 